See discussions, stats, and author profiles for this publication at: https://www.researchgate.net/publication/232758035

\title{
Sustainable Reclaimed Water Management by Subsurface Drip Irrigation System: a study case for forage production
}

Conference Paper · October 2007

\section{CITATIONS}

2

5 authors, including:

25

M del Pino Palacios-Díaz

Universidad de Las Palmas de Gran Canaria

102 PUBLICATIONS 430 CITATIONS

SEE PROFILE

J.R. Fernández-Vera

CABILDO DE GRAN CANARIA

42 PUBLICATIONS 290 CITATIONS

SEE PROFILE

\section{READS}

28

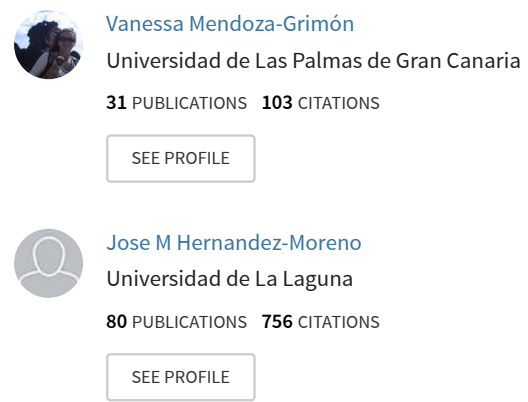

Some of the authors of this publication are also working on these related projects:

MITIMAC: Mitigación del cambio climático a través de la innovación en el ciclo del agua mediante tecnologías bajas en carbono" (MAC2/1.1a/263) View project

Adaptación al cambio climático en la macaronesia a través del uso eficiente del agua y su reutilización. Convocatoria Europea. PRIMERA CONVOCATORIA INTERREG MAC 2014-2020. MAC/3.5b/102 View project 


\title{
Sustainable Reclaimed Water Management by Subsurface Drip Irrigation System: a study case for forage production
}

\author{
M.P. Palacios*, V. Mendoza-Grimón*, F. Fernández**, J.R. Fernandez-Vera*** and \\ J.M. Hernandez-Moreno $* * * *$
}

\begin{abstract}
*Agronomía. Facultad de Veterinaria. Universidad de Las Palmas de Gran Canaria. P.O. Box 550, 35080 Las Palmas de Gran Canaria. Canary Islands. Spain. (E-mail: mpalacios@dpat.ulpgc.es)

**Consejo Insular de Aguas de Gran Canaria. Apartado oficial. 35011. Las Palmas de Gran Canaria

***Granja Agricola Experimental del Cabildo de Gran Canaria. Autovia Las Palmas Arucas km 6.535413 Arucas

****Departamento de Edafologia y Geología. Universidad de La Laguna. Av. Astrofisico F.Sanchez, s/n. 38206 La Laguna. Canary Islands. Spain.
\end{abstract}

\begin{abstract}
In the Canary Islands the price fluctuation of groundwater ( 0.3 to $0.7 € / \mathrm{m}^{3}$ ), which is a private resource, often limits the recovery of the agricultural investments. Availability of alternative resources (reclaimed water: RW, desalinized seawater: DW and desalinized reclaimed water: DRW) at a foreseeable price will allow people to design the optimal infrastructures adapted to their needs The pumping cost is included in the "public" water price of DW (0.6 €/m3), RW $(0.2 € / \mathrm{m} 3)$ and DRW $(0.42 € / \mathrm{m} 3)$, but only if it is under $300 \mathrm{~m}$ of altitude. As a subsurface irrigation system (SDI), uses the soil as a natural advanced (but not high cost) water treatment, the in situ reuse of RW produced by lower tech wastewater plants would provide a valuable resource for the small villages.

A successful study case is presented here. A 2-year SDI experiment was performed using RW, cultivating alfalfa (Medicago sativa) and Sudan grass hybrid (Sorghum bicolor ssp sudanense). Although a saline (EC: $2.24 \mathrm{dS} / \mathrm{m}$ ) and sodic (SAR: 6.9) water was used, irrigation with SDI led to high forage yields (between 8.4 and $11.9 \mathrm{~kg}$ of fresh matter $/ \mathrm{m}^{2}$ obtained by 8 harvests per year). However, sand filter and drip lines have to be cleaned weakly and every 6 months respectively. As a conclusion of this study, adequate plant germination and yields, and feasibility of SDI using a secondary effluent was demonstrated. Besides, water cost represents only 24 to $17 \%$ from the gross income.
\end{abstract}

Key words: advanced treatment, alfalfa, water-cost, reclaimed-water management, SDI, sudangrass hybrids

\section{INTRODUCTION}

In the Canary Islands, water scarcity is one of the constraints for agricultural activity. The islands have a volcanic origin with a subtropical climate. The main risk factors for soil degradation identified in Europe are: erosion, organic matter decline, compaction, salinisation and landslides (Eckelmann et al., 2006). Proper land use would prevent these problems but water is necessary to sustain agricultural activity. For instance, the most arid islands (Fuerteventura and Lanzarote) have an annual rain average of $150 \mathrm{~L} \cdot \mathrm{m}^{-2}$. In Gran Canaria, agriculture uses the $58 \%$ on the total consumption, about $75 \mathrm{Mm}^{3}$ (Consejo Insular de Aguas de Gran Canaria, 1998) and has to compete with other uses, like tourism, which is the basic economical income.

Aquifer overexploitation has led to a decline in water quality: from the total groundwater extracted, the $43 \%$ is pumped from non renewable resources (ground water represents $56 \%$ from the total consume while superficial resources or "fresh water" are only 7\%; Consejo Insular de Aguas de Gran Canaria, 1998).

The price fluctuation of groundwater and fresh water $\left(0.3\right.$ to $\left.0.7 € / \mathrm{m}^{3}\right)$, which is a private resource in these islands, often limits the recovery of the agricultural investments. As an example, water consumption involves from $30 \%$ (tomato) to $45 \%$ (banana) of the cost production. Availability of alternative resources at a foreseeable price, will allow people to design the optimal infrastructures adapted to their needs. Alternative resources are reclaimed water, desalinized seawater and desalinized reclaimed water (RW, DW and DRW). Small mountain villages use to transport their 
effluents to the high-tech wastewater plants near the most populated coastal areas. Due to the high cost of pumping, the RW produced by the treatment plants are located in the lower areas, and then, that water is not available to the people living in the mountains. As a consequence, the pumping cost is included in the "public" water price (without any subsidy) of RW $(0.2 € / \mathrm{m} 3)$ and DRW $(0.42 € / \mathrm{m} 3)$ for lands below $300 \mathrm{~m}$ of altitude (Consejo Insular de Aguas de Gran Canaria, 2004), while DW is from 0.5 to $0.6 € / \mathrm{m} 3$ (Consejería de Aguas Gobierno de Canarias, 2007). Thus, the in situ reuse of RW produced by lower tech wastewater plants would provide a valuable resource for the small villages and would eliminate the need for the costly transport of RW, DW or DRW from the lower areas. Forage production is the most suitable choice to reuse RW resources, due to its lower quality exigency and the lack of the fresh forage crops to feed livestock caused by the high water price (Palacios et al., 2005).

A disinfected secondary effluent could be used for drip irrigation, after a conventional sand media and mesh filtration, whenever a safety reuse is assured by an advanced but not high cost water treatment. Two points of view should be considered in any RW irrigation project: risk and sustainability principles. A subsurface irrigation system, SDI, uses the soil as a "natural advanced water treatment" resulting in a safe and profitable reuse. Design and management are closely linked in a SDI system. Besides, SDI must also have long life in order to be economically viable to produce the relative low value field crops (Rogers and Lamm, 2005), such as forages are. SDI has other advantages: water-conserving production practices, high yielding crops, prevention of the contact between water and stems and leaves minimizing sanitary risks (Camp, 1998). Sodium enrichment in soils affects its structural stability and its permeability (being estimated as hydraulic conductivity) and its holding capacity. Thus, the change in hydraulic conductivity is related to water EC and SAR but it is also affected by many other factors as $\mathrm{pH}$, soil texture and clay minerals, soil organic matter, water organic matter content, and water and soil management. Many studies are published about the estimation on structural stability related to water quality (Suarez et al., 1984, Ayers and Westcot 1985), but according to the numerous factors implied, the threshold levels must be adapted for RW irrigation under SDI management.

While salinity thresholds established for conventional resources are mainly related to $\mathrm{Cl}$ and $\mathrm{Na}$, RW carries out many other compounds. Thus, if proper fertilizer application program is calculated, higher EC levels of RW could be applied with no adverse effects on plant production (Palacios et al., 2000). Nitrogen, phosphorous and boron carried out by RW has also a critical effect in soils, crops and environment. Water management due to the irrigation system design and operation affects the medium and long time consequences.

The aim of this work was to evaluate agronomical and economical feasibility of RW reuse for the forage production applied by SDI system and to determinate the best SDI design and water management practices under experimental field conditions as a pilot reuse project.

\section{MATERIAL AND METHODS}

A two year irrigation experiment was performed using RW. The experimental field is located on the north coast of the Gran Canaria Island, Spain. The annual precipitation is $243 \mathrm{~mm}$ and the average annual temperature is $19.5^{\circ} \mathrm{C}$. The effects on the soil and forage (yield and quality) was monitored and compared with a control using conventional freshwater. Thus, the experimental field is divided in two zones, respectively irrigated with reclaimed water (RW) and fresh water (FW). Each water quality zone has its own pond, filtration system (sand and screen mesh) and pipeline network. Alfalfa (Medicago sativa) and sudangrass hybrid (Sorghum bicolor ssp sudanense*Sorghum bicolor ssp bicolor) were cultivated at the experimental site. No fertilizers were added. A SDI system was used for water distribution. The lateral lines were buried at $0.2 \mathrm{~m}$ depth. The experiment consisted 
of 8 irrigation treatments: 0.5 and $0.75 \mathrm{~m}$ emitter spacing, 0.5 and $1 \mathrm{~m}$ between lateral lines, and two types of emitters, both of them pressure compensating. The irrigation frequency depended on the climatic conditions, varying from daily to 3 times per week. Irrigation days, amount of water applied in each plot, and biweekly pressure readings were recorded. Water, plant and soil samples were collected and submitted to the laboratories for analysis. Water from 22 dates (since October 2001 to May 2003) were analyzed. Filtered RW (RWf) was also analyzed for the last 14 dates. Composed soil samples from all plots were collected before seeding and during the experiment, to carry out the chemical analysis and the soil texture determination in the laboratory. Selective soil sampling in June 2003 was performed in order to study salt and nutrient distribution around the emitters: the XY data were obtained from 3 distances apart from the drip line: 0, 0.25 and 0,50 m, and 4 different deeps under the soil surface: $0.1,0.2,0.3$ and $0.5 \mathrm{~m}$, for the soils irrigated by both RW and FW. Repetitive soil solution samples were obtained during the experiment using "Rhizon" samplers. Plant samples for nutrient determination were weighted directly after harvest on 26/03/03 and on 9/05/03 (Sudan grass), and on 28/05/03 (alfalfa). No fertilization program was used for any of the treatments. Forage was harvested by hand, when $10 \%$ of the crop was flowering. More detailed aspects of experimental design are presented in Palacios et al., 2005. Microbiological parameters were also determined but presented in another paper.

\section{RESULTS AND DISCUSSION \\ Water characteristics}

Irrigation RW had acceptable $\mathrm{BOD}_{5}$ values for drip irrigation $\left(16 \pm 5\right.$ and $12 \pm 6 \mathrm{mg} \cdot \mathrm{L}^{-1}$, before and after filtration respectively). However, in September 2002 and from May to August 2003, values greater than $150 \mathrm{mg} \cdot \mathrm{L}^{-1}$ were produced due to operation problems in the wastewater treatment plant. In spite of this, effective reduction was obtained after sand filtration since DBO5 values of filtrated RW was continuously below $125 \mathrm{mg} \mathrm{L}^{-1}$. This illustrates the effectiveness of the sand filtration step to protect the irrigation system.

Main water characteristics during the experiment are presented in table 1 . As observed, water quality of the two irrigation water treatments were different $(\mathrm{P}<0.05)$ in all the measured parameters with the exception of $\mathrm{pH}(\mathrm{P}>0.05)$. Irrigation $\mathrm{RW}$ showed a moderate degree of restriction on use regarding salinity and boron concentration, and no restriction concerning infiltration (Ayers \& Westcot, 1985). In other hand, as pointed out by Palacios et al. (2000) for bananas, the salinity threshold tolerance for crops due to the RW nutrient contribution is higher than obtained for conventional water resources. Comparing with preliminary results presented in Palacios et al. (2005), lower salinity (2.24 from 2.45) and SAR (6.94 from 8.36) are obtained, caused by the improvement of the wastewater plant design and management. A moderate degree of restriction was also shown for boron, nitrate and chloride. In relation to sustainability, the contents of B (0.19 (mmolc $\cdot \mathrm{L}^{-1}$, equivalent to $\left.2.0 \mathrm{mg} \cdot \mathrm{L}^{-1}\right)$, $\mathrm{P}\left(0.14 \mathrm{mmol} \cdot \mathrm{L}^{-1}\right.$ or $\left.4.21 \mathrm{mg} \cdot \mathrm{L}^{-1}\right)$, and $\mathrm{N}\left(1.66 \mathrm{mmol} \cdot \mathrm{L}^{-1}\right.$ or $23.27 \mathrm{mg} \cdot \mathrm{L}^{-1}$ ) exceeded the concentration limits proposed for long-term irrigation, respectively, 0.75, 0.05, and $5 \mathrm{mg} \cdot \mathrm{L}^{-1}$ (ANZECC, 2000; USEPA 2004) but are acceptable for short term criteria (2, $0.8-12$ and $25-125 \mathrm{mg} \cdot \mathrm{L}^{-1}$ respectively). The rest of the nutrients and metals in $\mathrm{RW}$ were acceptable for long-term irrigation.

Soil characteristics and water management control nutrient availability to plants. Factors affecting $\mathrm{B}$ availability in soils are solution $\mathrm{pH}$, soil texture (B adsorption depends on the clay content), soil moisture (Perkins in 1995 studied the soil moisture content effects in boron availability), temperature and organic matter content (Goldberg, 1997). Thus, water management will modify plant uptake. In this sense, SDI water management effect on boron availability are not enough studied. Soil, stems and leaves contents presented in this paper will allow us to increase this useful knowledge. 
Table 1. Chemical composition of RW and FW. Mean and (standard deviation) values from 21 waters samplings during the experiment.

\begin{tabular}{|c|c|c|c|c|c|c|}
\hline $\begin{array}{c}\text { Irrigation } \\
\text { Water }\end{array}$ & $\begin{array}{c}\text { EC } \\
\mathrm{dS}^{-1} \\
\end{array}$ & $\mathrm{pH}$ & \multicolumn{4}{|c|}{ mmolc $\cdot \mathrm{L}^{-1}$} \\
\hline FW & $0.15 \quad(0.14)$ & 7.15 (1.01) & $0.56(0.91)$ & $0.20(0.08)$ & $0.60(0.12)$ & $0.20(0.19)$ \\
\hline \multirow[t]{2}{*}{ RW } & $(0.75)$ & $7.76(0.56)$ & $14.55(5.97)$ & $1.40(0.46)$ & $3.86(1.24)$ & $4.93(2.15)$ \\
\hline & $\begin{array}{c}\mathrm{TSS} \\
\mathrm{mg} \cdot \mathrm{L}^{-1}\end{array}$ & $\begin{array}{c}\text { SAR } \\
\left(\mathrm{mmol} \cdot \mathrm{L}^{-1}\right)^{1 / 2}\end{array}$ & $\mathrm{Cl}^{-}$ & \multicolumn{2}{|c|}{ mmolc $\cdot \mathrm{L}^{-1}$} & $\mathrm{NO}_{3}^{-}$ \\
\hline FW & $3.03(3.40)$ & 0.88 & $0.59(1.12)$ & $0.09(0.12)$ & $1.11(0.98)$ & $0.01(0.01)$ \\
\hline \multirow[t]{3}{*}{ RW } & $17.87(3.76)$ & 6.94 & $12.10(5.45)$ & $3.8(0.76)$ & $9.03(2.24)$ & $0.9(1.3)$ \\
\hline & \multirow[t]{2}{*}{$\mathrm{NH}_{4}$} & $\mathrm{Pt}$ & $\mathrm{B}$ & $\mathrm{Fe}$ & $\mathrm{Mn}$ & $\mathrm{Zn}$ \\
\hline & & mmolc $\cdot \mathrm{L}^{-1}$ & & & $\mu \mathrm{mol} \cdot \mathrm{L}^{-1}$ & \\
\hline FW & $0.01(0.01)$ & DL & DL & $0.53(1.08)$ & $0.14(0.31)$ & $0.32(0.31)$ \\
\hline RW & $0.77(0.81)$ & $0.14(0.09)$ & $0.19(0.06)$ & $7.84(23.08)$ & 0.7 (1.25) & 3.35 (3.83) \\
\hline
\end{tabular}

TSS: suspended solids Pt: total phosphorus $\quad$ Alk: alkalinity $\quad$ DL: Under detection limit

\section{Soil}

The field plot was an old tomato orchard, in fallow for more than 20 years. The soil was a clay loam (27.6\% clay), originally saline and sodic (ESP 24\%) and could be classified as Anthrosol (FAO, 1998) or Torriarent (Soil Survey Staff, 1998)..

Soil characterization during the experiment is presented in table 2. As observed, very high values of EC in soils irrigated by RW were obtained in the summer of 2003. This soil salinity is above the threshold limit even for tolerant crops as alfalfa and sudan grass hybrid. As expected, lower salinity and nitrate levels were found in soils irrigated by FW. As alfalfa is a legume and the sudan grass hybrid was not cultivated in FW irrigated soil, no $\mathrm{N}$ fertilization was needed. Organic matter content was higher in FW soils as compared to RW. This apparently contradictory result is consistent with other authors (Magesan et al., 1999). The soil can be classified as rich regarding phosphorus contents. Thus, the crops were able to absorb enough $\mathrm{P}$ without using any $\mathrm{P}$ fertilizer, as leaves contents were in the acceptable interval. However, the greater P Olsen contents measured in FW soils should be further studied.

Table 2: Evolution of soil properties during the experiment

\begin{tabular}{|c|c|c|c|c|c|c|c|c|c|c|}
\hline \multirow{2}{*}{$\begin{array}{l}\text { Date } \\
\text { Irrigation Water }\end{array}$} & \multirow{2}{*}{\multicolumn{2}{|c|}{ 09/2001 }} & \multirow[t]{2}{*}{$04 / 2002$} & \multirow[t]{2}{*}{$11 / 2002$} & \multirow[t]{2}{*}{$02 / 2003$} & \multicolumn{2}{|c|}{$06 / 2003$} & \multicolumn{2}{|c|}{$07 / 2003$} & \multirow{2}{*}{$\begin{array}{c}12 / 2003 \\
\text { RW }\end{array}$} \\
\hline & & & & & & RW & FW & RW & FW & \\
\hline $\mathrm{EC}_{\mathrm{s}^{*}}$ & & & 5.02 & 4.26 & 3.81 & & & 15.33 & 2.69 & 8.25 \\
\hline pH-water & & & 7.9 & 7.9 & 8.3 & 8.0 & 7.9 & 7.8 & 8.2 & 7.8 \\
\hline Ca Carbonate (\%) & & & 4.6 & 5.5 & 4.0 & 3.3 & 4.0 & 4.4 & 4.8 & 4.2 \\
\hline Organic C (\%) & & & 0.56 & 0.52 & 0.19 & 0.41 & 0.8 & 0.51 & 0.7 & 0.62 \\
\hline C-D Fe** & & & 0.96 & 0.89 & 0.33 & 0.71 & 1.36 & 0.88 & 1.26 & 1.07 \\
\hline Ex Cations*** & $\mathrm{K}$ & 4.6 & 4.0 & 4.7 & 3.8 & 5.0 & 7.4 & 6.5 & 5.5 & 4.3 \\
\hline & $\mathrm{Na}$ & 7.0 & 10.1 & 8.3 & 7.6 & 9.5 & 18.5 & 23.6 & 8.8 & 8.8 \\
\hline & $\mathrm{Ca}$ & 8.0 & 12 & 12.8 & 12.8 & 14.8 & 16.9 & 15.5 & 14.9 & 12.8 \\
\hline & $\mathrm{Mg}$ & 8.8 & 7.9 & 9.0 & 8.5 & 9.1 & 10.2 & 10.7 & 9.7 & 9.5 \\
\hline Olsen P(mg/kg) & & 28 & 41 & 40 & 22 & 27 & 64 & 32 & 48 & 36 \\
\hline $\mathrm{NO}_{3}-\mathrm{N}_{\mathrm{S} * * * *}$ & & & & 250 & 97 & 90 & & 120 & 25 & 200 \\
\hline $\begin{array}{l}\text { *ECs:electrical } \\
\text { conductivity }\end{array}$ & & & Extract & & & $\begin{array}{l}\text { Fe: } \\
\text { nitre }\end{array}$ & . & & Ex C & $\begin{array}{l}\left(\mathrm{cmol}_{\mathrm{c}} .\right. \\
\mathrm{mg} / \mathrm{kg})\end{array}$ \\
\hline
\end{tabular}


The selective soil sampling EC results measured at the end of the experiment were drawn by SURFER 8 (Golden Software, 2002) software from the XY data for the soils irrigated by both RW and FW. Thus, the figure 1 shows the Electrical Conductivity (EC) distribution in the soil profile. Different scale was used due to the high differences of EC values between RW and FW soil, caused by the salinity of the RW.
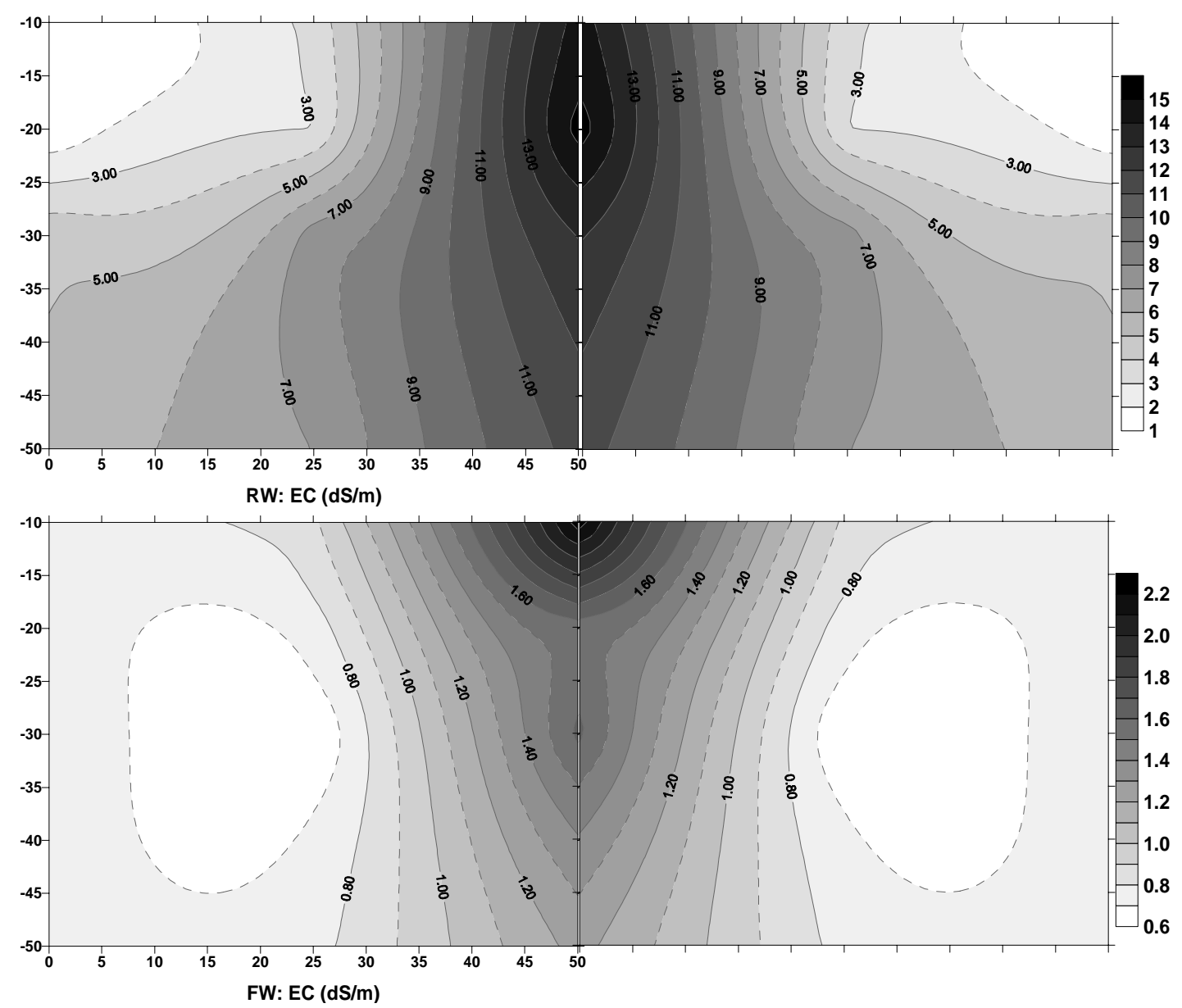

Figure 1: Electrical Conductivity (EC) in the soil profile. XY data were obtained from 3 distances apart from the drip line: $0,0.25$ and 0,50 m, and 4 different deeps under the soil surface: $0.1,0.2,0.3$ and $0.5 \mathrm{~m}$ ). Symmetric figure is also drawn to represent the whole profile, as the drip lines are buried $1 \mathrm{~m}$ apart from each other.

As expected, higher salinity is obtained in RW irrigated soils. Salinity distribution coincides with results obtained by Assadian et al., (2005) who mentioned higher EC values in soils subirrigated using RW at $0.1 \mathrm{~m}$ below the soil surface. As observed, water management related to the SDI system governed the salinity profile: higher EC values were measured at the top and between the drip lines. EC values between lines coincided with those obtained by conventional soil sampling. This fact was also confirmed by the negative effect of salinity on the crop yields.

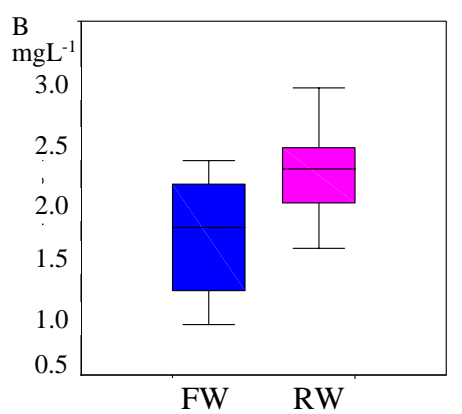

Soluble boron concentration was higher in RW soils than in $\mathrm{FW}$, as presented in figure 2. In spite of this, no adverse effect was observed in crops therefore alfalfa and sudan grass hybrid are boron tolerant species.

Figure 2: Average Boron concentration in soil solution obtained from Rhizon samplers in RW and FW plots. 


\section{Crops irrigated using a SDI system}

Previous studies have demonstrated the feasibility of alfalfa production irrigated by SDI system (Hutmacher et al., 1992; Mead et al., 1992; Mc Gill y Hutmacher, 1993 and Hutmacher et al., 1996). A decrease in irrigation water use under SDI was reported when this was compared with spray irrigation on grain sorghum (Colaizzi et al., 2003), using 50 and 25\% levels of water applied.

As previously mentioned in Palacios et al., (2005) the water salinity did not affect first germination and shooting that were adequate in all irrigation treatments of our study. It is contradictory with Lamm (2002) who mentioned that salinity could be a problem under this irrigation system and reduce the alfalfa germination rate. That result was obtained in spite of no additional irrigation was used, although it is mentioned to be necessary (Camp 1998). It is possible that the unusual heavy rainfalls had some role in mitigating high salinity of the soil. A heavy weed growth (even when a chemical control was applied) required reseeding of the alfalfa plots from the second and the third blocks. Seeding again was possible since the irrigation system was under the ground and allowed to sow without inducing any disturb. That should be considered as another advantage of this SDI system.

Figure 3 shows the yield for alfalfa and sudan grass hybrid during the year 2003. The first alfalfa harvest had to be rejected due to weed infection. Water quality was significant for alfalfa production except for the most productive month (June) for RW and the lowest one (November) for FW. Thus, the yields are represented separately for FW and RW. The greater difference by water quality was found in may 2003, coinciding with the highest salinity obtained in RW soils. Although alfalfa is a salinity tolerant crop, the high EC values obtained between the irrigation lines had affected alfalfa production.
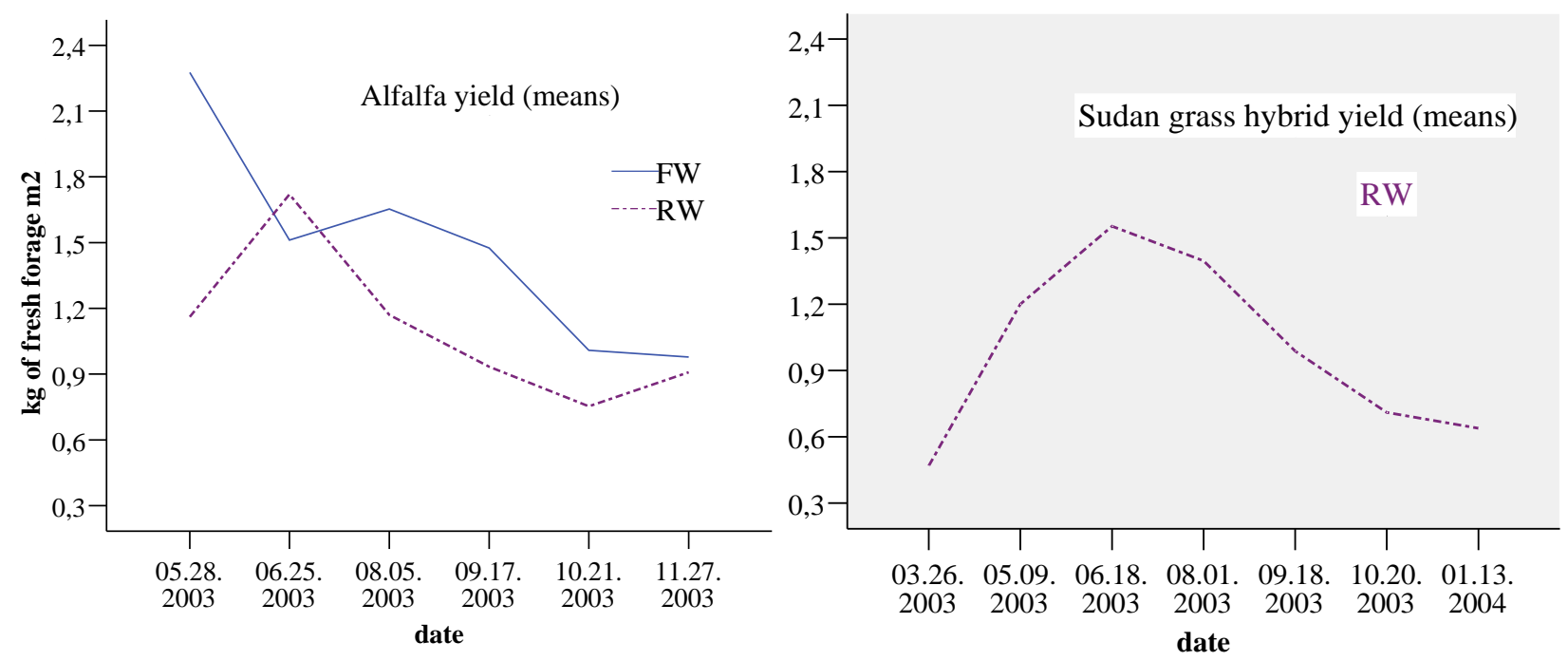

Figure 3: yield for alfalfa and sudan grass hybrid during the year 2003

As expected, statistical differences were obtained by date for both crops, producing the highest yield in spring and the lowest in winter. Similar production was obtained for both crops in summer (not very hot in Canary Islands) but slightly lower production was obtained by sudan grass in winter (alfalfa has a C3 metabolism and sudan grass hybrid is a C4). In fact, sudan grass had no production from 20 October to January while alfalfa had another harvest in November 27, although with the lowest yield. Our mean value per harvest for sudan grass irrigated using RW was $1.05 \mathrm{~kg}$ of fresh forage per $\mathrm{m}^{2}$. Considering 8 harvest per year (no cut from December to February), the accumulated yield for a year is $8.39 \mathrm{~kg} \cdot \mathrm{m}^{2}\left(17 \mathrm{Mg}\right.$ of dry matter per ha ${ }^{-1}$ ). Higher sudan grass hybrid yield was mentioned by Serra et al., (2005) who obtained a mean value for two years of $25.5 \mathrm{Mg} \cdot \mathrm{ha}^{-1}$ of dry 
matter, although they harvested only 2 times by each year in the north of Spain. These authors do not mention the quantity of irrigation water used for their study and had small plots of $6 \mathrm{~m}^{2}$ that probably affected the results.

The soil moisture distribution obtained for all the irrigation treatments was sufficient for effective plant growth. In our study water moved horizontally more than $0.6 \mathrm{~m}$ from the drip lines and reached the soil surface above the lateral line. In fact, the significantly higher yield observed in the first cutting in the closer lateral spacing $(0.5 \mathrm{~m}$ as compared to $1 \mathrm{~m})$ disappeared after the second alfalfa cut. These results for alfalfa production are consistent with obtained by Alam et al., (2002) in semi-arid Kansas, who concluded that it is more economical to use the $1 \mathrm{~m}$ spacing. The same results were obtained for sudan grass. No significant differences were obtained from the differences by the emitter spacing ( 0.5 and $0.75 \mathrm{~m}$ ), nor by the two types of emitters (two commercial irrigation materials adapted for irrigation using RW).

The SDI system maintenance was monitored: sand filter and drip lines have to be cleaned weakly and every 6 months respectively when irrigating with RW. Thus, effective filtration was able to protect the irrigation system from clogging was obtained using conventional equipment.

As a conclusion, water quality, date and its interaction give an explanation model for the obtained alfalfa yield with a $\mathrm{R}^{2}$ of 0.65 . All of these variables are significant for the model.

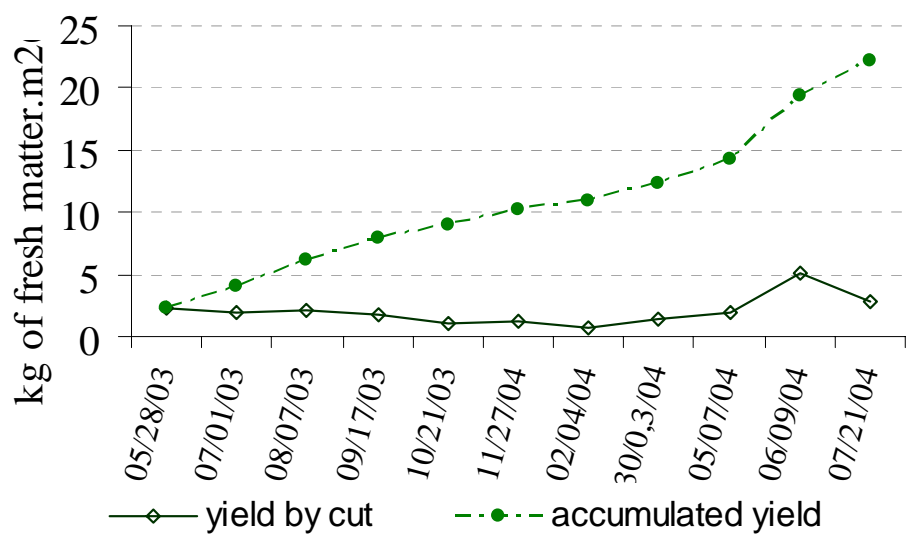

Figure 4: alfalfa production by harvest and accumulated yield irrigated using FW during 14 months
Figure 4 represents the alfalfa yields (in $\mathrm{kg}$ of fresh matter per $\mathrm{m}^{2}$ ) obtained for each harvest and accumulated yield during a more extended period of time (14 months). As presented here, it is possible to obtain 9 harvests per year, and to reach an annual yield of $143 \mathrm{Mg}$ of fresh matter per hectare (equivalent to $28.6 \mathrm{Mg}$ of dry matter $\cdot \mathrm{ha}^{-1}$ ) irrigating with non limiting water quality. Water consumption was measured by the installed flowmeters for each treatment. All of them used $600 \mathrm{~L} \cdot \mathrm{m}^{-2}$ per year which

Although a saline (EC: $2.24 \mathrm{dS} / \mathrm{m}$ ) and sodic (SAR: 6.94) water was used, irrigation with SDI resulted in an effective production of forage (between 8.4 and $11.9 \mathrm{~kg}$ of fresh matter $/ \mathrm{m}^{2}$ obtained by 8 or 9 harvests per year). As demonstrated, using FW the yields can be even higher. The salinity problems found in RW irrigated soils negatively affected the crop production. Lower salinity water should be used if the maximum yields are needed. However, enough production is obtained using the RW quality presented in this case study. Neither nutrient deficiencies nor imbalances were observed, suggesting the contribution from irrigation water and probably from residual soil forms.

The price of hey forage is $0.24 € / \mathrm{kg}$. Considering the lower estimated annual yield of $8.4 \mathrm{~kg}$ of fresh matter $\cdot \mathrm{m}^{-2}$ (equivalent to 2.1 dry matter. $\mathrm{m}^{-2}$ ), the gross income is $0.5 € \cdot \mathrm{m}^{-2}$. As RW cost is $0.2 € \cdot \mathrm{m}^{-3}$ and $600 \mathrm{l} \cdot \mathrm{m}^{-2}$ are applied by SDI system, it can be calculated that the cost of RW represents less than $24 \%$ of the total income. Thus it is possible to cultivate many abandoned soils in Canary Island to obtain enough forage for animal production. Obviously, obtaining a higher forage yield 
(11.9 $\mathrm{kg}$ of fresh matter $\cdot \mathrm{m}^{-2}$ ) than that presented for alfalfa or when harvesting nine times per year, the ratio will be even lower (17\%).

\section{CONCLUSIONS}

The proposed water, soil and crop production system is able to produce the forage even in the winter in Canary Islands. Due to the high water volumes required for the fodder crop production, only the use of RW presents a possibility for sustaining this activity in the island. In this study adequate crop emergency, performance and yield, and feasibility of SDI when reusing reclaimed water was demonstrated as no adverse effect is observed in the irrigation system. The farming land operations are compatible with the installation of the subsurface drip irrigation. The cost of RW represents less than $24 \%$ of the gross income even using this salinity water. Higher yield should be expected reducing the RW salinity

\section{ACKNOWLEDGEMENTS}

The authors sincerely acknowledge the Granja Agricola Experimental y Consejo Insular de Aguas del Cabildo de Gran Canaria and Ministerio de Ciencia y Tecnología (RH 2006) for the financial assistance, Dr Francisco Echavarria and F Rodriguez (Granja Agrícola) for their valuable advices.

\section{BIBLIOGRAPHY}

Alam, M., T. P. Trooien, T. J. Dumler and D. H. Rogers.2002 Using Subsurface Drip Irrigation for Alfalfa. Journal of the American Water Resources Association. Vol.38, No.6, 1-7.

ANZECC y ARMCANZ (2000). Australian guidelines for water quality monitoring and reporting. National Water Quality Management Strategy Paper No 7, Australian and New Zealand. Environment and Conservation Council \& Agriculture and Resource Management Council of Australia and New Zealand, Canberra.

Ayers RS y Westcot DW (1985). Water quality for agriculture. Irrigation and Drainage Paper 29, 1st revision, Food and Agriculture Organisation of the United Nations, Rome.

APHA (1995). Standard Methods for the Examination of Water and Wastewater. 19th Ed. American Public Health Association. Washington.

Assadian NW, Di Giovanni GD, Enciso J, Igleisas J and Lindemann W 2005. The transport of waterborne solutes and bacteriophage in soil subirrigated with wastewater blend. Agriculture, Ecosystems and Environment 111:279-291

Camp C.R. (1998). Subsurface drip irrigation: A Review. Transaction of ASAE: VOL. 41 (5): 1353-1367.

Colaizzi, P.D.; Barnes, E.M.; Clarke, T.R.; Haberland, J.H.; Choi, C.Y.; Waller, P.M. 2003. Water Stress Detection under High Frequency Sprinkler Irrigation with water deficit index. ASCE Journal of Irrigation and Drainage Engineering 129(1): 36-44.

Consejo Insular de Aguas de Gran Canaria, CIAGC (1998). Plan Hidrológico de Gran Canaria (Hydrologycal Balance). CIAGC (2004). Boletín Oficial de la Provincia de Las Palmas (Las Palmas Gazette), 26 marzo 2004: 4280-4282

Consejería de Aguas Gobierno de Canarias (2007). El agua en Canarias (Water in Canary Islands) http://www.gobcan.es/citv/dga/aguacanarias.html

Eckelmann W., Baritz R., Bialousz S., Bielek P., Carre F., Houšková B., Jones R.J.A., Kibblewhite M.G., Kozak J., Le Bas C., Tóth G., Tóth T., Várallyay G., Yli Halla M. and Zupan M. (2006). Common Criteria for Risk Area Identification according to Soil Threats.European Soil Bureau Research Report No.20, EUR 22185 EN, 94pp. Office for Official Publications of the European Communities, Luxembourg.

FAO, E.L., 1998. World Reference Base for Soil Res World Soil Resources Reports, vol. 84. FAO Roma pp21- 22. Goldberg, S.1997. Reactions of boron with soils. Plant and Soil 193: 35-48

Hutmacher R.B., Phene C.J., Mead R.M., Clark D., Shouse P., Vail S.S., Swain R., van Genuchten M., Donovan. T., Jobes J., (1992). Subsurface drip irrigation of alfalfa in the Imperial Valley. Proceedings, $22^{\text {nd }}$ California/Arizona alfalfa Symposium, University of CA and University of AZ Cooperative extension, Holtville, CA, December 9-10, 22:20-32. Hutmacher RB., Mead R.M., Shouse P. (1996). Subsurface Drip: Improving Alfalfa Irrigation in the West. Irrigation Journal, 46(1): 48-52.

Lamm, R. 2002. Advances and disadvances of subsurface drip irrigation.” International meeting of advances in drip/Irrigation”. Puerto de La Cruz, Canary Islands. December 2-5

Magesan, G., Williamson, J., Sparling, G., Schipper, L. y Lloyd-Jones, A. (1999). "Decreased hydraulic conductivity in soils irrigated with waste waters of different strengths: field and laboratory studies”. Austr J of Soil Res 37, 391-402. 
McGill S., Hutmacher RB. (1993). Buried Drip for Alfalfa? The Furrow 98(7):26-27, November-December.

Mead R.M., Hutmacher R.B. and Phene C.J. (1992). Subsurface drip irrigation of alfalfa. Proceedings, CIT/USDA-ARS

Seminar on Subsurface Drip Irrigation: Theory, Practice and Application, Harris Ranch C. CA Oct 22, pp. 177-178.

Palacios M.P., Haman D., Del-Nero E., Pardo A.., and Pavón N. (2000) Banana production irrigated with treated effluent in Canary Islands. Transaction of the ASAE. 43(2)309-314

Palacios M.P., Mendoza-Grimon V., Fernadez J.R., Del-Nero E., Tejedor M., Lupiola P., Rodriguez E., Pita L. and Rodriguez F. (2005) Reclaimed water management in mountain areas of semiarid regions for safe animal production (to feed animals and to irrigate forage crops). EAAP publication Animal Production and natural resources utilization in the Mediterranean mountain areas. Vol No 155 (183-189).

Perkins P.V. (1995). The consideration of soil boron adsorption and soil solution boron concentration as affected by moisture content. Geoderma 66:99-111

Rogers D.H. and Lamm F.R (2005) Key considerations for a successful subsurface drip irrigation (SDI) system. In proceedings of the Central Plains Irrigation Conference, Sterling, CO, Feb. 16-17. Available from CPIA, 760 N. Thompson, Colby, KS. Pp 113-118.

Serra J., Salvia J and Solsona M.S. (2005) Producción y valor nutritivo de variedades comerciales de sorgo forrajero y de híbridos de sorgo $\times$ pasto del sudán normales y "Brown Midrib, en el nordeste de Cataluña. Yield and nutritive value of Sorghum and Sudan grass hybrids. In: Producciones agroganaderas: Gestión eficiente y conservación del medio natural (Vol II) pp:505-512XLV Reunión Científica de la SEEP (Sesión Prod. Vegetal) (available in http://www.seepastos.es/ Asturias 2005)

Soil Survey Staff (1998). Keys to Soil Taxonomy, $8^{\text {th }}$ ed. USDA-NRCS, Lincoln.

Suarez D.L., Rhoades J.D., Lavado R. and Grieve, C.M. 1984. Effect of pH on saturated hydraulic conductivity and soil dispersion. Soil Sci. Soc. Am. J., 48:50-55.

USEPA (2004): "Guidelines for wastewater reuse”. US Environmental Protection Agency. EPA/625/R-04/108. Washington, DC. 